九病虫研会報 45：119-122（1999）

Kyushu Pl. Prot. Res. 45 : 119-122 (1999)

\title{
集合フェロモン製郕を利用したチャバネアオカメムシの 発生量および被害の予測
}

\section{1. 集合フェロモントラップとライトトラップによる誘殺消長の比較}

\author{
中村 吉秀・西野 敏勝
}

(長崎県果樹試験場)

\begin{abstract}
Forecasting fruit damage caused by the brown-winged green bug, Plautia stali SCOTT, and its occurrence using synthetic aggregation pheromone traps.

1. Comparison of the seasonal prevalence of catches between an aggregation pheromone trap and a light-trap. Yoshihide NAKAMURA and Toshikatu NisHino (Nagasaki Fruit Tree Experiment Station, Omura, Nagasaki 856-0021)
\end{abstract}

Key word: aggregation pheromone, forecasting, fruit damage, Plautia stali

チャバネアオカメムシは果樹への飛来が多いカメムシ で，時として果実に甚大な被害を及ぼしており(阿万， 川崎，1997；井手5，1997；西野·中村，1997)，最近 は数年ごとに大発生を繰り返している（福元ら，1992； 農林水産省果樹試験場，1997；佐藤ら，1997；山田ら， 1991)。本種の発生予察は常緑広葉樹の落葉中における 越冬量調查打よび指標植物上での寄生虫数調查，ヒノキ のきゅう果量調査，水銀灯などの光源を用いたライトト ラップによる誘殺消長調查等を併用して行われているが (山田・野田，1984；山田ら，1983)，野外におうる正確 な発生量の把握や果実の被害を予測することは難しい。 また，本種の雄成虫は同種の雌および雄成出を誘引する 集合フェロモン在放出することが明らかになっており (守屋，1995；MORIYA and SHIGA，1984），雄成虫を誘 引源としたトラップによる発生予察を試みた報告もある (福田ら，1996；年屋，1995；大橋，1996)。しかし，雄 成虫を用いて発生予察を行う場合，大量の雄成虫を継続 的に人丁飼有しなければならず，雄成虫の生理状態など により集合フェロモンの放出量が安定しないことが推测 されるため，予察資材として沉用化することは難しい。

近年, 雊成虫が放出する集合フェロモンの化学構造が 決定され (SUGIE et al, 1996)，合成された集合フェロモ ン製戍を朋いた試験が可能となった。この製戍による誘 殺消長や果実被害と誘殺消長の関係を調べた例は少なく， 本製剛が発生予祭用資材として利用可能かは明らかでな い。そこで，集合つェロモン製威を利用したチャバネア オカメムシの発生量調稫法, とくに発生量と被害との関
係を究明するため，従来から使用されているライト卜 ラップによる誘殺消長との比較および誘殺消長と果実の 被害との関係，効率的な集合フェロモントラップの種類 について検討した。なお，報告に先立ちチャバネアオカ メムシおよび集合フェロモンの取り扱いに関して御指導 頂いた，福岡県農業総合試験場大平喜男室長（現果樹試 験場カンキツ部)，堤隆文専門研究員に打礼申し上げる。

\section{材料および方法}

\section{1. 集合フェロモン製剤}

集合フェロモン製剮は，信越化学工業で合成された集 合フェロモン約 $40 \mathrm{mg}$ が封入された $10 \mathrm{~cm}$ のロプタイプ ディスペンサーを使用した。

集合フェロモン製郕の交換は約30日閣隔で行ったが， 7 ～8 月は約20日間隔で交換した。

2. トラップの種類と設置場所

1）集合フェロモントラップ

集合フェロモントラップはサンケイ化学のコガネムシ 用誘引器コガネコールの黄色タイプと, 直畦 $60 \mathrm{~cm} の$ 青色 のタライに水を張った水盤トラップの2 種類を使用した。 コガネコールトラップは高さ $1.7 \mathrm{~m}$ の位置に支柱で固定 し，水盤トラップは地上 $0.5 \mathrm{~m}$ の高さに設置し，フェロ モン製剤を地上 $1.0 \mathrm{~m}$ の高さに，針金で固定した。

\section{2) ライトトラップ}

ライトトラップは地上 $1.7 \mathrm{~m}$ の高さに $20 \mathrm{w}$ の宣光色蛍 光灯 2 基を取り付け，そのすぐ下に $80 \mathrm{~cm}$ 四方の水盤を置 き，日没とともに点灯するように設置した。 


\section{3) トラップの設置場所}

試験に用いた 2 種の集合フエロモントラップとライト トラップは大村市にある長崎県果樹試験場内に設置した (第 1 図)。集合フェロモントラップはライトトラップの 光源が直接見えない場所で, 約 $33 \mathrm{~m}$ 離れた地点にコガ ネコールトラップを，さらに $22 \mathrm{~m}$ 離れた地点に水盤卜 ラップを設置した。2種類の集合フェロモントラップは 設置場所を 5〜7日每に入れ替えた。

トラップ設四場所の周辺環境は, 約 $300 \mathrm{~m}$ 離れた地点 にヒン丰林が，約50m離れた地点にクリ，スダジイの林 があり，ライトトラップはカンキッ園の横に，集合フェ ロモントラップはブドウ園の園沿いに設置した。

\section{3. カメムシ類の誘殺消長調查}

1998年 4 月13日〜11月30日まで，1３日間隔で，各 トラップに誘殺されるカメムシ類の誘殺数を種類, 雌雄 別に調べた。

\section{4. 果実の被害調查}

果実の被害調查では，第 1 図に示したナシ圃場に10本 植栽されている品種幸水の果実を 5 月15日～７月20日ま で約15日毎に採集し，果皮上にあるカメムシ類の唾液鞘 数を調べた。1 回の採集果実数は20３0個とした。

唾液鞘数は果実を $0.5 \%$ 酸性フタシン液で約 3 分間染 色し，水洗後に実体顕微鏡下で調べ，果実に唾液鞘が認 められたものを被害果実とし，被害果率および 1 果当た

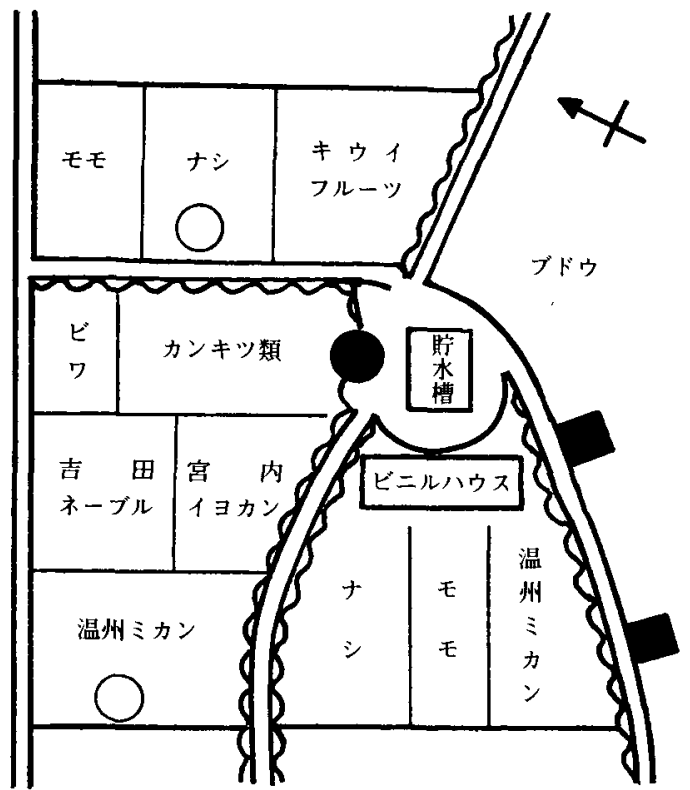

第 1 図試験逋場の植栽図および各種トラップの設真埸所 ○ライトトラップ 固合フェロモントラップ ○ナシおよび温州ミカンの被害調査図 防風坦
りの唾液鞘数を算出した。

温州ミカンの果奏被害についてもナシと同様の方法で 調べた。第 1 罒に示した温州ミカン阑場に8 本植栽され ている品種與津早生の果実を 8 月31日〜11月17日まで約 20日每に採集し，果皮上の唾液鞘数を調查した。

ナシおよび温州ミカンの調查樹には, カメムシ類に活 性のある合成ピレスロイド剤, 有機リン率, クロロニコチ ニル剤は散布せず，殺菌㓲および IGR 剤のみ散布した。

結 果

1. 集合フェロモントラップとライトトラップによる 誘殺消長の比較

1998年のチャバネアオカメムシ成虫の誘殺消長は，越 冬成虫の飛来時期である 4 ～ 7 月はライトトラップと集 合フェロモントラップのコガネコールトラップ（以下集 合フェロモントラップと省略)でほぼ同じであった(第2 四)。新成虫の飛来時期である 8 月以降は，誘殺数が両 トラップで異なり，ライトトラップの場合，8月に少な $く, 9$ 月中旬〜 10月中旬に数回の明暸なピークが出現し た。こ机に対して集合フェロモントラップの場合は，8 月以降10月まで一定量以上のカメムシが常に誘殺された。

两トラップで飛来量が多かった 4 月下旬〜 5 月上旬招 よび 9 月下旬〜 10 月中旬のピーク時の最多誘殺数は, 集 合フェロモントラップよりライトトラップの方が多かった。

\section{2. 果実被害の推移と誘殺消長との関連}

ナシ果奏に打ける被害果率は5月中旬から下旬にかけ て，また果皮上の唾液鞘数は 5 月15日〜30日および 6 月 15日～30日の間に，それぞれ急速に高まった（第 3 図）。 それぞれの時期に対応するこれらの誘殺ピークがライト トラップおよび集合フェロモントラップの両方で確認さ れた（第 2 図)。而ピークは，5月15日ー6月30日の間 に認められた誘殺ピークの中では，他のピークよりも誘 殺量が多かったが，カメムシ類による果実の加害時期を トラップによる誘殺消長から推測することは難しかった。

温州ミカンに招ける被害果率は，8月下旬か59月下 旬にか计て高まった（第 3 図）。集合フェロモントラッ プではこの時期に多くの誘殺ピークが認められ，ナシの 場合のように果実の被書増加時期に対応する特定のピー クは識別できなかった。ライトトラップでは 2 回の 誘殺ピークが認められたが，被害の増加時期との関係は 不明であった。

\section{3.トラップの種類の違いが誘殺消長に及ぼす影響}

コガネムシ用誘引器のコガネコールトラップ (黄色) と直待 $60 \mathrm{~cm}$ のライ（青色）に水を張った水盤トラップ を用いて，トラップの種類が誘殺消長に及ぼす影響につ 
いて調べた。雨トラップによるチャバネアオカメムシの 誘殺消長はやや異なり，コガネコールトラップでは 4 月 下句および 5 月上旬, 8 月以降の誘殺数が多かったのに 対して，水艋トラップでは 7 月中旬一 8 月上旬が多かっ た(第 2 図)。誘殺ピークの出現時期は両トラップでおよ そ共通していたが，ピーク時の誘殺数は水盤トラップよ りコガネコールトラップの方が多い傾向であり，4月一 11月の総誘殺虫数はコガネコールトラップが水盤トラッ プの約 2 倍と多かった(第 2 図, 第 1 表)。

各トラップに誘殺された成虫における雌の比率は，コ ガネコールトラップで58\%，水盤トラップで63\%とほぼ 同じであった（第 1 表）。ライトトラップにおける雌の 比率も60\%で，集合フェロモントラップとライトトラッ
プに誘殺される成虫の性比に差は認められなかった。

これらの集合フェロモントラップにはチャバネアオカ メムシ以外に, ッヤアオカメムシとクサギカメムシが誘

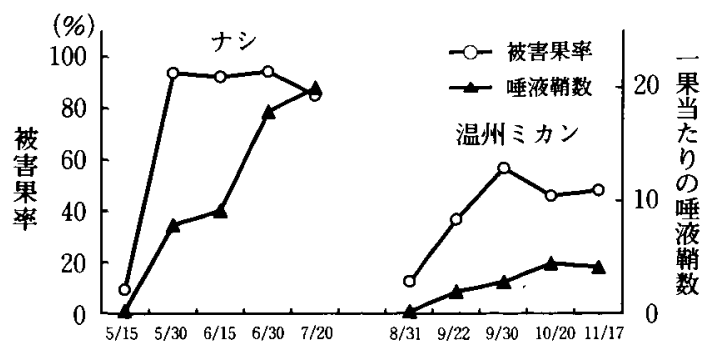

第3図ナシおよび温州ミカン果実のカメムシ類による被害の 推移 (1998年調查)
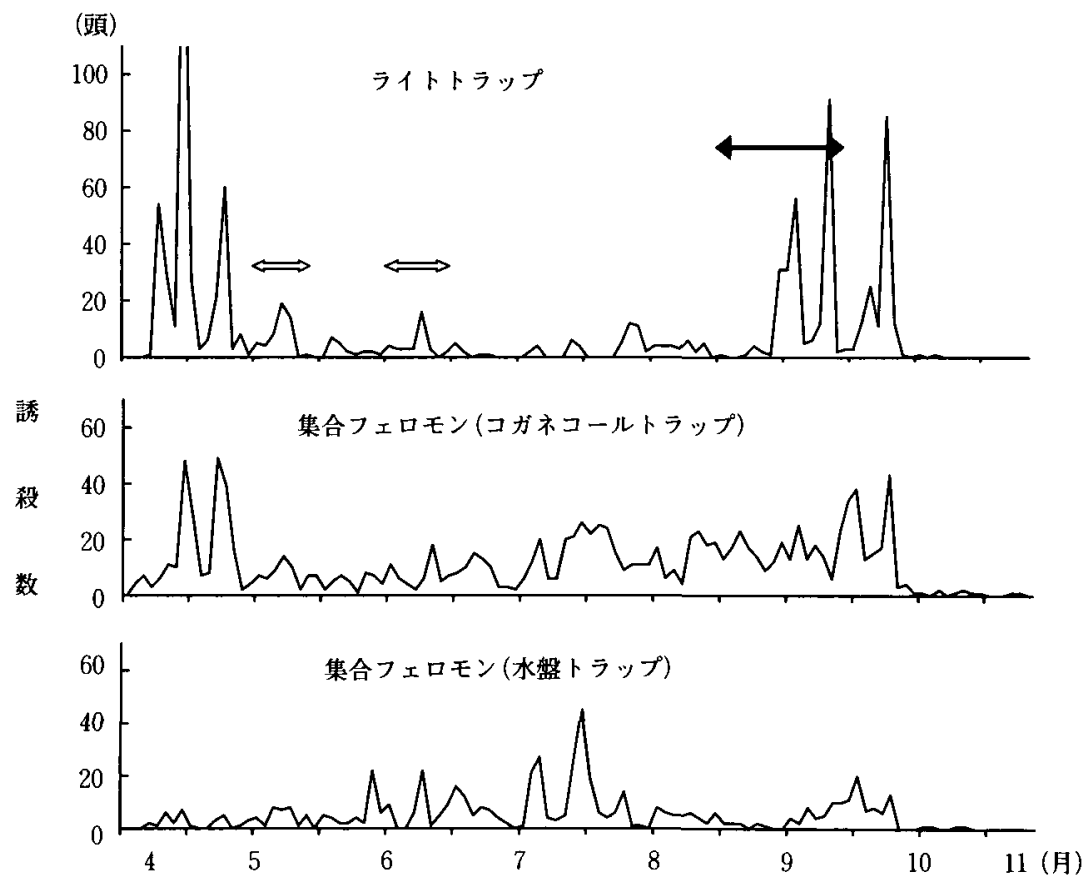

第2図 集合フェロモントラップとライトトラップによるチャバネアオカメムシ成虫の誘䄫消長 誘殺数㹥 2 日毎の頭数。1998年調査。 $\Longleftrightarrow$ なシ果実の被害增加時期

$\longleftrightarrow$ 温州ミカン果実の被害增加時期

第 1 表 集合フェロモンとライトトラップに誘殺されるカメムシ類の誘殺数 ${ }^{1)}$

\begin{tabular}{|c|c|c|c|c|c|c|c|c|c|c|}
\hline \multirow{2}{*}{ トラップの㮔類 } & \multicolumn{3}{|c|}{ チャバネアオカメムシ } & \multicolumn{3}{|c|}{ ッナアオカメムシ } & \multicolumn{3}{|c|}{ クサギカメムシ } & \multirow{2}{*}{ 天敵 ${ }^{21}$} \\
\hline & 雌 & 雄 & 計 & 雌 & 雄 & 計 & 雌 & 雄 & 計 & \\
\hline \multicolumn{11}{|l|}{ 集合フェロモン } \\
\hline コガネコールトラップ & 725 & 518 & 1243 & 568 & 660 & 1228 & 18 & 16 & 34 & 244 \\
\hline 水盤トラップ & 355 & 208 & 563 & 205 & 227 & 432 & 13 & 13 & 26 & 32 \\
\hline ライトトラップ & 596 & 394 & 990 & 1114 & 1325 & 2439 & 8 & 7 & 15 & 3 \\
\hline
\end{tabular}

1）1998年 4 月13日 11月30日の総誘殺成虫数。

2) 天敵はマルホシハナバエ成虫。 
殺された。コガネコールトラップでは，チャバネアオカ メムシに対してッャアオカメムシがほぼ同数，クサギカ メムシが約 $1 / 40$ 誘殺された。水盤トラップではッヤアオ カメムシが約 $4 / 5$ ，クサギカメムシが約 $1 / 20$ 誘殺された (第 1 表)。ライトトラップでは, ッヤアオカメムシが約 2.5倍, クサギカメムシは約 $1 / 70$ 誘䄫され，ッヤアオカ メムシの総誘殺成虫数がチャバネアオカメムシより多い 点で，集合フェロモントラップの場合と異なっていた。 これら他のカメムシ類の発生予察が集合フェロモント ラップにより可能かはさらに検討が必要であった。

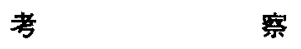

集合フェロモン製剤を利用したチャバネアオカメムシ の発生量および被害の予測法について検討した。越冬成 虫では集合フェロモントラップによる誘殺消長は，ライ トトラップによる誘殺消長とよく一致したことから，某 合フェロモントラップを用いてもライトトラップと同様 の予察が可能であると考えられた。しかし，8月以降の 新成虫では両トラップの誘殺消長が異なり，どちらのト ラップが真の発生消長を表すのか, 不明であった。雄成 虫を用いた集合フェロモントラップによる調查でも，新 成虫の誘殺消長がライトトラップと一致しない報告が多 いが（福田ら，1996；守屋, 1995 ; 大橋, 1996 ; 大平, 1997），一致した例もあり（大平·堤，1996），今後，誘 殺消長に違いを生じさせる要因の解明が必要である。

両トラップの多飛来時における最多誘殺数は, ライト トラップが集合フェロモントラップより多かった。ライ トトラップにおける成虫の誘引範囲は光が届く範囲なの で, トラップから遠い地点でも誘引されるが, 集合フェ ロモンは有効な誘引範囲が半径約 $10 \mathrm{~m}$ 程度（大平・津田, 1995）とされており，誘引範囲の違いにより最多誘殺数 に差が生じたと推察された。

越冬成虫の加害による果実被害の增加時期には，これ に対応する誘殺ピークが集合フェロモントラップとライ トトラップで認められたのに対して，新成虫の加害時期 では被害の增加と誘殺消長との関係は不明であった。果 実被害の増加時期はカメムシの果樹園への飛来・侵入時 期とも考えられる。このため，チャバネアオカメムシの 発生予察をより精密に行うためには，果実の被害と各卜 ラップにおける誘殺消長との関係，とくに新成虫が飛来 する時期の関係を明確にする必要がある。また，果実を 加害する主要なカメムシ類として，チャバネアオカメム シ以外にもッャアオカメムシ，クサギカメムシが知られ ている。本試験でもッヤアオカメムシが誘殺され，その 数は集合フェロモントラップではチャバネアオカメムシ
とほほ同数、ライトトラップでは約2.5倍誘殺された。 ツヤアオカメムシの誘殺時期は集合フェロモントラップ とライトトラップでほぼ一致し，4月中勾〜 5 月下旬と 9 月上旬 10月中旬に集中していた。この時期はチャバ ネアオカメムシが多く誘殺された時期の一時期と重なっ ていた。すなわち、ッヤアオカメムシもチャバネアオカ メムシと同じ時期に果樹園へ飛来し，果実を加害したこ とが推祭された。したがって，果樹カメムシ類による果 実の被害を予測するには，チャバネアオカメムシだけで なく, ツヤアオカメムシの発生量や本種による被害の発 生との関連についても解明する必要がある。

トラップの種類とカメムシ類の誘殺消長との関係は, コガネムシ用誘引器のコガネコールトラップが，タライ を用いた水盤トラップよりも誘殺量, 誘殺ピークの明膫 さのいずれの点でも優れていた。この原因としては， ト ラップの形状，集合フェロモンの設置位置（高さ）など が考えらる。つまり，形状としてはトラップと垂直に衝 突板がついているほうが良く,フェロモンの高さは $1.0 \mathrm{~m}$ よ $1.7 \mathrm{~m}$ と高い方が，カメムシ類を効率上く捕獲 できるようである。したがって，集合フェロモン製剛を 利用したチャバネアオカメムシの発生予察にはコガネ コールトラップが実用的であると考えられた。

\section{引 用 文 献}

1）阿万暢彦・川崎安夫（1997）九病虫研会報 43：145（講 要)。2）福田宽·上遠野富士夫・横山とも子・藤家 梓 (1996) 平成 7 年度果樹課题別会議資料：27-33. 3) 福元 博·寺本 敏・山本栄一·黙本文代 (1992) 九病虫研会報 38 ： 166-169.4) 井手洋一・岩永秀人. 安西隆・ 末次信行 - 田 代暢战一松崎正文 (1997) 九病虫研会報 43：110-113。 5）守屋成一 (1995) 沖縄農試特報 5:1-135. 6) MORIYA, S. and M. ShigA (1984) Appl. Ent. Zool. 19 : 317-322. 7) 西野敏勝・中村吉秀 (1997) 平成 8 年度常緑果樹試験研究 成縝蔇要集 虫害編：43-46, 8) 農林水産省果樹訆験場 (1997)「果樹カメムシ類異常大発生に関する祭急調榃研究」実 施報告菖：1-36.99) 大橋弘和. (1996) 平成 7 年度果樹課題 別会議資料：34-41. 10) 大平喜男 (1997) 平成 8 年度果樹課 題别会議資料：28-33.11）大平喜男・津田勝男（1995）九病 虫研会報 $41: 137$ (講要)。12）大平喜男 - 堤 隆文 (1996) 平成 7 年度常緑果樹試験研究成績概要集 虫害編: $52-53$. 13）佐藤兑助-中村利宣-角里花 (1997) 九病虫研会報 43 ： 114-116. 14) Sugie, H., M. Yoshida, K. Kawasaki, H. Noguch, S. Moriya, K. Takagi, H. Hukuda, A. Fujie, M. Yamanaka, Y. Ohira, T. Tsutsumi, K. Tsuda, K. Fukumoto, M. .Yamashita and H. SUZuKi (1996) Appl, Ent. Zool. 31 : 427-431。 15）山田健一- 野田政春（1984）福岡農総試研報B 4:17-24. 16) 山田健一・野田政春·野口忠広·能本勝已 （1983）九病虫研会報 $29 ： 158-163.17 ）$ 山田健一一堤隆 文・津留嘉成・才田英雄・篠倉正住 (1991) 九病虫研会報 37： 183-187.

(1999年4月30日 受領) 